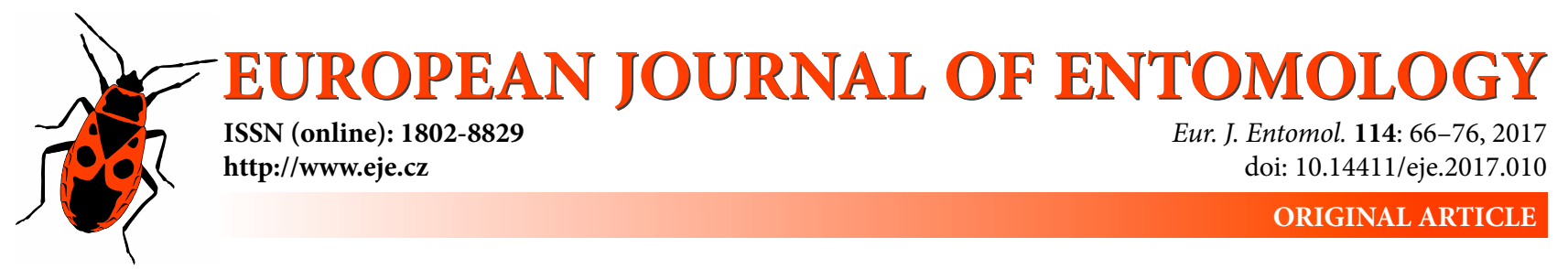

\title{
Do flower mixtures with high functional diversity enhance aphid predators in wildflower strips?
}

\author{
Séverin HATt ${ }^{1,2,3}$, Roel UYTtenbroeCK ${ }^{1,4}$, Thomas LOPES ${ }^{2}$, Pierre MOUChON $^{2,5}$, Julian CHEN $^{3}$, \\ JULIEN PIQUERAY ${ }^{6}$, ARnaUd MONTY ${ }^{4}$ and Frédéric FRANCIS ${ }^{2}$
}

\author{
1 TERRA - AgriculturelsLife, Gembloux Agro-Bio Tech, University of Liège, Passage des Déportés 2, 5030 Gembloux, Belgium; \\ e-mail: severin.hatt@ulg.ac.be \\ ${ }^{2}$ Functional and Evolutionary Entomology, Department of Agronomy, Biology and Chemistry, Gembloux Agro-Bio Tech, \\ University of Liège, Passage des Déportés 2, 5030 Gembloux, Belgium; e-mails: tlopes@doct.ulg.ac.be, \\ frederic.francis@ulg.ac.be \\ ${ }^{3}$ State Key Laboratory for Biology of Plant Diseases and Insect Pests, Institute of Plant Protection, Chinese Academy \\ of Agricultural Sciences, 2 West Yuanmingyuan Rd., Haidian District, 100193 Beijing, China; e-mail: jlchen@ippcaas.cn \\ ${ }^{4}$ Biodiversity and Landscapes, Department of Biosystems Engineering, Gembloux Agro-Bio Tech, University of Liège, \\ Passage des Déportés 2, 5030 Gembloux, Belgium; e-mails: roel.uyttenbroeck@ulg.ac.be, arnaud.monty@ulg.ac.be \\ ${ }^{5}$ Institut Supérieur d'Agriculture de Lille, 48 boulevard Vauban, 59046 Lille, France; e-mail: mouchonpierre@gmail.com \\ ${ }^{6}$ Natagriwal asbl, Passage des Déportés 2, 5030 Gembloux, Belgium; e-mail: jpiqueray@natagriwal.be
}

Key words. Syrphidae, Coccinellidae, Chrysopidae, agri-environmental measure, conservation biological control, wildflower strips, functional diversity, Rao's index

\begin{abstract}
Among the semi-natural elements in agricultural landscapes, wildflower strips sown at field margins or within fields are potential habitats for the natural enemies of insect pests. As insects are sensitive to a variety of flower traits, we hypothesized that mixtures with high functional diversity attract and support a higher abundance and species richness of aphid flower visiting predators than mixtures with low functional diversity. During a field experiment, repeated over two years (2014 and 2015) in Gembloux (Belgium), aphid predators (i.e., lacewings, ladybeetles and hoverflies) were pan-trapped in five sown flower mixtures (including a control mixture, with three replicates of each mixture) of low to high functional diversity based on seven traits (i.e., flower colour, ultra-violet reflectance and pattern, start and duration of flowering, height and flower class, primarily based on corolla morphology). In both years, the species of flowering plants in the sown mixtures (i.e., sown and spontaneous flowers) were listed, and the realized functional diversity in each plot calculated. Over the two years, a high functional diversity was not associated with high abundance and richness of aphid predators. Moreover, ladybeetles, which made up the majority of the predators trapped, were more abundant in mixtures with very low or intermediate functional diversity at sowing, especially in 2014 . We hypothesize that certain flowers, which were abundant in certain mixtures (and not in those exhibiting the highest functional diversity), attracted predators and were sufficiently abundant to support them. Our results present novel information that could be used for developing flower mixtures that provide effective ecosystem services, such as pest control.
\end{abstract}

\section{INTRODUCTION}

Wildflower strips (WFS) are one of several types of habitats used by insects in agricultural landscapes (Holland et al., 2016). There is extensive evidence that, when sown at field margins, WFS support a higher abundance and diversity of insects compared to adjacent crops (reviewed by Haaland et al., 2011). Indeed, WFS provide insects with floral food (such as nectar and pollen), as well as alternative prey and hosts for insect predators and parasitoids, respectively. WFS also provide insects with overwintering sites and shelters against adverse conditions, such as pesticide spraying (Landis et al., 2000). For these reasons, subsidizing the sowing of WFS is part of the agri-environmental policy in the European Union (EU) and some other countries in Europe. Indeed, within the EU, part of the direct payments is conditional on farmers implementing various ecological measures, including the maintenance of "ecological focus areas", such as field margins (i.e. "greening of direct payment" in Pillar 1, Hodge et al., 2015). Moreover, agri-environmental schemes (Pillar 2), which may be adopted by farmers on a voluntary basis, were developed to "reduc[e] environmental risks associated with modern farming on the one hand, and preserve nature and cultivated landscapes on the other hand" (European Commission, 2005). More recently, there have been calls to diversify agri-environmental schemes to include measures enhancing 
ecosystem services, in addition to approaches that purely aim to support biodiversity (McKenzie et al., 2013; Ekroos et al., 2014). Among other ecosystem services (Zhang et al., 2007), the natural regulation of insect pests is of particular interest when considering the damaging effects of insecticides on human health and the environment (Devine \& Furlong, 2007; Baldi et al., 2013) and the resistance of pests to insecticides (Foster et al., 2007).

Conservation biological control is defined as "the use of tactics and approaches that involve the manipulation of the environment (i.e., the habitat) of natural enemies so as to enhance their survival, and/or physiological and behavioural performance, and resulting in enhanced effectiveness" (Barbosa, 1998). When applied to WFS, such manipulations consist of sowing mixtures that support natural enemies. Yet, enhancing natural enemies through habitat management might not necessarily lead to pest control. In addition to the five hypotheses proposed by Tscharntke et al. (2016), the resources and shelter provided by WFS might retain natural enemies, limiting their ability to control pests in adjacent crops (Rand et al., 2006). Moreover, simply sowing flowers might not generate a higher abundance of key beneficial species in strips, and reduce the abundance of pests in adjacent crops (Uyttenbroeck et al., 2016). One explanation is that some natural enemies might not be attracted to the species of flowers that are sown, or, if they are, might not find the resources that they need (Wäckers, 2004). Therefore, several studies have explored the effects of specific flower species on insect behaviour in order to select the species that effectively attract and support the beneficial ones (Tooker et al., 2006; Fiedler \& Landis, 2007a; Van Rijn \& Wäckers, 2010; Carrié et al., 2012). However, the functional traits of flowers must be assessed in order to understand why some flower species are suitable for insects, and why some are not.

Traits are defined as "any morphological, physiological or phenological feature measurable at the individual level" (Violle et al., 2007). When traits are considered in the environment in which a plant grows, they may affect ecological processes, and are qualified as functional (Díaz \& Cabido, 2001). Several studies have explored the effect of flower traits on the behaviour of natural enemies using laboratory experiments, monospecific plots in fields or plants in pots (Mondor \& Warren, 2000; Schaller \& Nentwig, 2000; Fiedler \& Landis, 2007b; Miller et al., 2013; Van Rijn \& Wäckers, 2016). The shape of the corolla is another flower trait, which determines how insects access the food provided by flowers. This trait has been extensively studied because many natural enemies need pollen and nectar at certain stages in their development (Lu et al., 2014; Van Rijn et al., 2016). Other morphological traits, such as colour and ultra-violet (UV) reflectance, are involved in host plant recognition and, thus, flower attractiveness (Chittka et al., 1994; Campbell et al., 2010), while plant height might affect their flight (Wratten et al., 2003). Finally, phenological traits, such as the month of the onset and duration of flowering, might be important, because the food pro- vided by flowers must be available when the insects need it (Colley \& Luna, 2000).

The extensive literature available on how flower traits affect natural enemy behaviour highlights that different insect species respond differently to the same trait. Therefore, it is hypothesized that mixing flower species with different values for these traits, generating a high functional diversity (FD) at the mixture level, will attract and support a high diversity and abundance of insects. Previous studies showed that plant mixtures with high FD benefit both natural enemies and pollinators (Fontaine et al., 2006; Campbell et al., 2012; Balzan et al., 2014). However, the high FD in these studies was based on an increased diversity in types of corolla, which determines the availability of food resources. Because insects are sensitive to several other flower traits, the present study aimed to explore whether a high FD in flower mixtures based on a multiplicity of traits enhances their use by flower visiting aphid predators. Our results are expected to provide baseline information for developing effective WFS mixtures for use in agricultural landscapes.

\section{MATERIAL AND METHODS}

\section{Study design}

Field experiments were conducted during the 2014 and 2015 growing seasons in a 9 ha field of the experimental farm belonging to Gembloux Agro-Bio Tech (University of Liège), Namur Province, Belgium $\left(50^{\circ} 34^{\prime} 03^{\prime \prime} \mathrm{N} ; 4^{\circ} 42^{\prime} 27^{\prime \prime} \mathrm{E}\right)$. The field was characterized by a loamy soil that drains naturally (Service Public de Wallonie, 2014). Before starting this experiment, the field was managed conventionally (i.e. synthesised fertilisers and pesticides were applied), and winter wheat was grown the previous year. No particular soil treatments were implemented before the experiment. A forest (i.e. l'Escaille natural reserve) is present on the north-west side of the field, while a young agroforestry system (planted in 2013) is present on the north-east side. Five WFS $(125 \mathrm{~m} \times 8 \mathrm{~m})$ were sown in 2013 . Each strip was divided into five equally sized plots $(25 \mathrm{~m} \times 8 \mathrm{~m})$, i.e., a total of 25 plots. These plots were sown with five different flower mixtures in a Latin square design. Three out of the five strips were assessed due to logistic constraints and work force limitation (Fig. 1). Four of the five mixtures contained seven flower species and three grass species (Festuca rubra, Agrostis spp. and Poa pratensis). The fifth mixture (control, C) only contained the three grass species (Table 1). All flowering plants are native perennial species that are commonly found in Belgian grasslands (benefits of such species, compared to exotic and/or annual species are reviewed by Fiedler \& Landis, 2007a), are typically used in agrienvironmental schemes in Wallonia, Belgium, and are available commercially (seeds were obtained from ECOSEM, Belgium). Flower species $\left(0.5 \mathrm{~kg} \cdot \mathrm{ha}^{-1}\right.$ of each, see Table 1$)$ and grass species (Festuca rubra: 11.5 kg.ha-1 ${ }^{-1}$ Agrostis spp.: 5 kg.ha- ${ }^{-1}$; Poa pratensis: $5 \mathrm{~kg} \cdot \mathrm{ha}^{-1}$ ) were sown on $6^{\text {th }}$ June 2013. Equal seed masses of the flower species were sown so that the species were similarly abundant. Species with lower seed mass are expected to suffer a greater mortality and, thus, might need more seeds compared to species with higher seed mass in order to obtain the same abundance (Turnbull et al., 1999). Each year, WFS were mown at the end of June and September. Adjacent to WFS, oilseed rape (Brassica napus L.) was grown from September 2013 to June 2014, while winter wheat (Triticum aestivum L.) was grown from October 2014 to July 2015. 


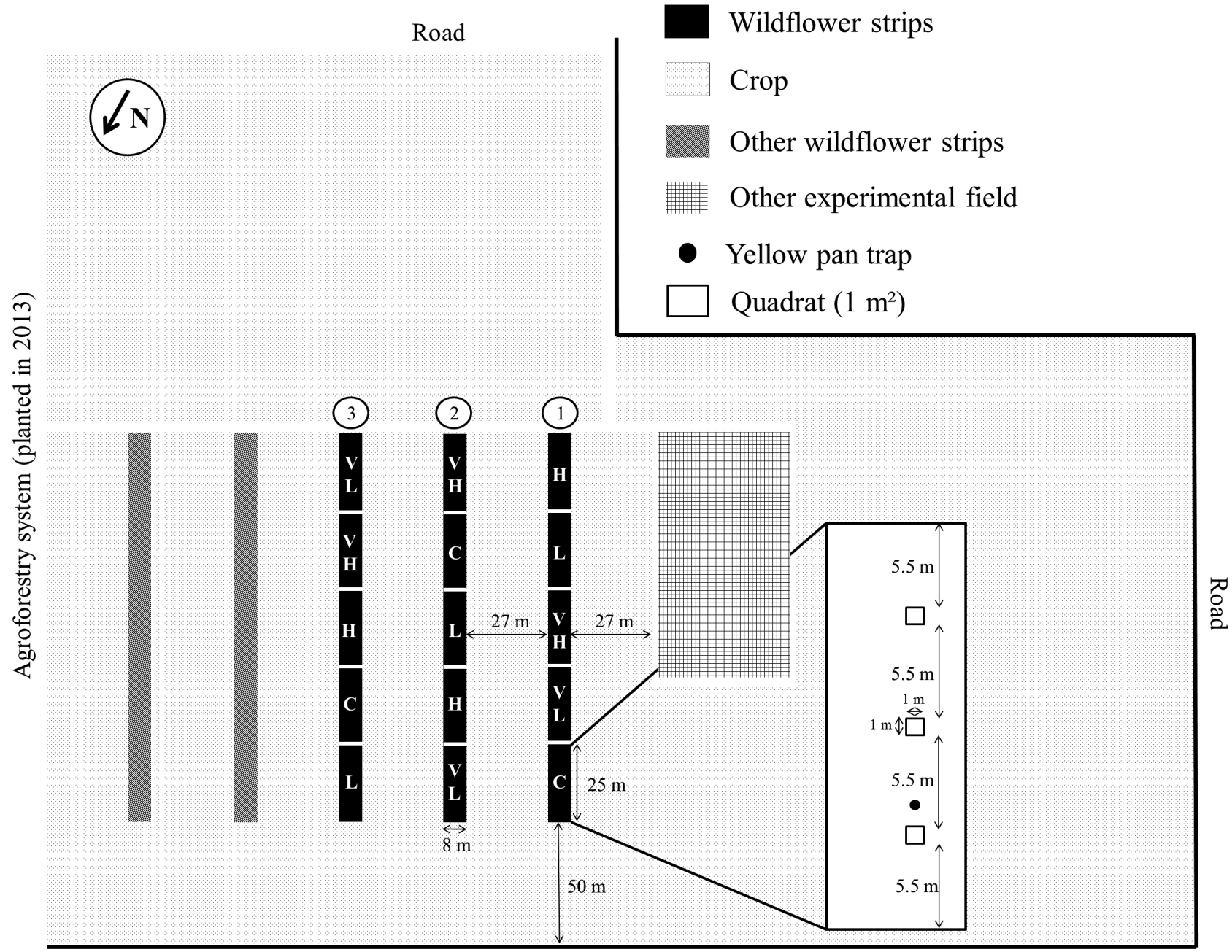

Forest edge

Fig. 1. Experimental field design. $\mathrm{C}$ - control, $\mathrm{VL}$ - very low, $\mathrm{L}-$ low, $\mathrm{H}-$ high, and $\mathrm{VH}$ - very high are the five flower mixtures sown described in terms of their functional diversity at sowing.

Table 1. Flower mixtures sown in June 2013, constituting a gradient of functional diversity based on Rao's index. C - control, VL very low, $\mathrm{L}-$ low, $\mathrm{H}$ - high, $\mathrm{VH}$ - very high. All flowering species were perennial species that are commonly found in Belgian grasslands and used in agri-environmental schemes in Wallonia, Belgium.

\begin{tabular}{|c|c|c|c|c|c|c|}
\hline \multirow{2}{*}{ Family } & \multirow{2}{*}{ Species } & \multicolumn{5}{|c|}{ Mixtures / Functional diversity (Rao's index) } \\
\hline & & $\mathrm{C} / 0$ & $\mathrm{VL} / 0.08$ & $\mathrm{~L} / 0.11$ & $\mathrm{H} / 0.15$ & $\mathrm{VH} / 0.19$ \\
\hline & Flowering species & & & & & \\
\hline Apiaceae & Anthriscus sylvestris & & $\mathrm{x}$ & & $x$ & $\mathrm{x}$ \\
\hline Apiaceae & Heracleum sphondylium & & $x$ & & & \\
\hline Asteraceae & Achillea millefolium & & $\mathrm{x}$ & $\mathrm{x}$ & $\mathrm{x}$ & $\mathrm{x}$ \\
\hline Asteraceae & Crepis biennis & & & $\mathrm{x}$ & & \\
\hline Asteraceae & Hypochaeris radicata & & & $\mathrm{x}$ & & \\
\hline Asteraceae & Leontodon hispidus & & & $x$ & $\mathrm{x}$ & \\
\hline Asteraceae & Leucanthemum vulgare & & $x$ & & $\mathrm{x}$ & \\
\hline Dipsacaceae & Knautia arvensis & & $x$ & $x$ & & \\
\hline Fabaceae & Lotus corniculatus & & & & & $x$ \\
\hline Fabaceae & Medicago lupulina & & & & & $\mathrm{x}$ \\
\hline Fabaceae & Trifolium pratense & & $\mathrm{x}$ & & & \\
\hline Geraniaceae & Geranium pyrenaicum & & & & $\mathrm{x}$ & \\
\hline Lamiaceae & Origanum vulgare & & & & $x$ & \\
\hline Lamiaceae & Prunella vulgaris & & & & $\mathrm{x}$ & $\mathrm{x}$ \\
\hline Lythraceae & Lythrum salicaria & & & $\mathrm{x}$ & & $\mathrm{x}$ \\
\hline Malvaceae & Malva moschata & & & & & $\mathrm{x}$ \\
\hline Rubiaceae & Galium verum & & $x$ & $x$ & & \\
\hline & Grass species & & & & & \\
\hline Poaceae & Agrostis spp. & $x$ & $\mathrm{x}$ & $\mathrm{x}$ & $x$ & $\mathrm{x}$ \\
\hline Poaceae & Festuca rubra & $\mathrm{x}$ & $\mathrm{x}$ & $\mathrm{x}$ & $\mathrm{x}$ & $\mathrm{x}$ \\
\hline Poaceae & Poa pratensis & $x$ & $\mathrm{x}$ & $\mathrm{x}$ & $\mathrm{x}$ & $\mathrm{x}$ \\
\hline
\end{tabular}




\section{Sown functional diversity}

The four flower mixtures (the fifth one being the control) were chosen based on their FD values using Rao's quadratic index (Botta-Dukát, 2005). To create the mixtures, 20 flower species were chosen and described based on seven of their functional traits that were retrieved from Lambinon et al. (2008) and the TRY database (Kattge et al., 2011) (Table S1). The seven traits were chosen based on their potential effect on flower visitors. First, visual cues are known to be decisive for insects when selecting a plant (Campbell et al., 2010). Hence, the following traits were considered: (i) flower colour, (ii) UV reflectance of the peripheral part of the flower, and (iii) whether the UV reflectance of the internal flower part differed from that of the external part (also called "UV pattern"). Second, flowering phenology determines whether floral resources are available when target insects need them (Colley et al., 2000). Therefore, (iv) the month of the onset of flowering and (v) the duration of flowering were chosen. Third, (vi) vegetation height was included, because it might affect insect flight (Wratten et al., 2003). Fourth, (vii) flower class after Müller (1881) was used, because it provides a measure of the the availability of nectar for insects that visit flowers, which determines whether WFS are able to support natural enemies (Van Rijn et al., 2016). All of the possible combinations of mixtures of seven species were listed, and their FD value was calculated ( $R$ function "divc", package "ade4"; Dray \& Dufour, 2007). Combinations with the lowest and the highest FD were selected, as well as those with a value closest to the $33^{\text {rd }}$ and the $67^{\text {th }}$ percentile of the range. As a result, four mixtures were generated with contrasting FD, termed very low (VL), low (L), high $(\mathrm{H})$ and very high $(\mathrm{VH})$ (Table 1).

\section{Realized functional diversity}

To evaluate the effect of the realized FD of the mixtures on flower visiting aphid predators, the effective composition of the flower mixtures was assessed each year. In three $1 \mathrm{~m} * 1 \mathrm{~m}$ permanent quadrats in each plot (Fig. 1), flower species were recorded and their relative cover estimated on 18-19 June 2014 and 19-23 June 2015 (before mowing). The nomenclature of Lambinon et al. (2004) was followed. Based on the species of flowers listed (both sown and spontaneous), their traits and their relative cover in the quadrats, the realized FD of the mixture in each plot was calculated.

\section{Monitoring of insect species}

Flower visiting predators were trapped from 7 May to 25 June 2014 and from 12 May to 30 June 2015 (i.e. for seven weeks in both years). In each plot, a yellow pan trap (Flora ${ }^{\circledR}, 27 \mathrm{~cm}$ diameter and $10 \mathrm{~cm}$ depth) was installed on a fiberglass stick and positioned at vegetation height. Its position was adjusted during the growing season to follow plant growth. Traps were filled with water containing a few drops of detergent (dish-washing liquid) to reduce the surface tension of the water. The traps were emptied and refilled every seven days, and the trapped insects were conserved in $70 \%$ ethanol. Aphidophagous ladybeetles (Coleoptera: Coccinellidae), as well as lacewings (Neuroptera: Chrysopidae) and hoverflies (Diptera: Syrphidae), the larvae of which prey on aphids, were identified to species using identification keys in San Martin (2004), van Veen (2010) and Roy et al. (2013), respectively. Because the adults of these predatory families are all highly mobile and able to traverse agricultural landscapes (Evans, 2003; Villenave et al., 2006; Almohamad et al., 2009), their dispersion through the different plots was comparable.

\section{Statistical analyses}

First, the linear relation between the sown and realized FD in each plot was tested for both years by using Pearson's correlation $(\mathrm{P}<0.05)$.

Second, the effects of the sown mixtures on insect abundance (response variables: all predators pooled, and lacewings, ladybeetles, hoverflies individually) and total predator species richness (species of the three predator families pooled) were assessed by fitting generalised linear mixed effect models (R function "glmer", package "lme4"; Bates et al., 2014) with Poisson error distribution (log-link function). Mixtures (C, VL, L, H, VH), years $(2014,2015)$ and their interaction were included as fixed factors, and the plots included as random effects, as measures were repeated on seven consecutive occasions in the same plots each year. For every model, data over-dispersion was tested and found to occur for the summed predator, ladybeetle and hoverfly abundance. For these variables, generalised linear models with negative binomial error distribution were fitted ( $\mathrm{R}$ function " $\mathrm{glm}$. nb", package "MASS", Venables \& Ripley, 2002), as suggested by Ver Hoef \& Boveng (2007). The effects of fixed factors in every model were tested using likelihood-ratio tests $(\mathrm{P}<0.05)$. When their interaction was significant, analyses were performed for each year separately.

Third, the effect of the realized FD on insect abundance (response variables: all predators pooled, and lacewings, ladybeetles, hoverflies individually) and total predator species richness (numbers of species of the three predator families pooled) were assessed for each year separately, as each year each plot potentially had a different value of FD, by fitting generalised linear mixed effect models. FD values were included as fixed factors and plots were included as random factors. Data over-dispersion was tested and found to occur for the summed predator, ladybeetle and hoverfly abundance in 2014. Thus, generalised linear models with negative binomial error distribution were fitted instead. The effects of realized FD in every model were tested using likelihood-ratio tests $(\mathrm{P}<0.05)$. All analyses were done using $\mathrm{R}$ program (R Core Team, 2013).

\section{RESULTS}

\section{Flower cover, species and functional diversity}

Twenty-one and 20 flower species were recorded in the quadrats in 2014 and 2015, respectively (Table 2), out of which eight species in both years were not sown. Among these spontaneous species, Cirsium arvense and Sinapis alba had the highest cover in plots in 2014, whereas in 2015 it was C. arvense and Rumex obtusifolius (Table 2). The cover of all other spontaneous species never on average exceeded $3 \%$ of the quadrat surface in each plot. Conversely, three of the sown species, Anthriscus sylvestris, Heracleum sphondylium and Lythrum salicaria, were not recorded in either year, with Origanum vulgare also not recorded in 2015.

The values of the realized FD in 2014 and 2015 are given in Table 2. Except for the C plots, the values of the realized FD were lower than those of the sown mixtures. No significant correlations were found between the sown and realized FD in both $2014(\mathrm{df}=13 ; \mathrm{r}=0.48 ; \mathrm{p}$-value $=0.071)$ and $2015(\mathrm{df}=13 ; \mathrm{r}=0.22 ; \mathrm{p}$-value $=0.423)$.

\section{Aphid predator abundance and diversity}

Predators were significantly more abundant in 2014 than 2015 (i.e. 161 and 51 individuals trapped respectively, Ta- 
Table 2. Realized functional diversity (FD, Rao's index) and mean cover (\%) of each flower species in each plot (C - control, VL - very low, $\mathrm{L}$ - low, $\mathrm{H}$ - high, VH - very high; the numbers are the number of replicates of each mixture sown; see Fig. 1), based on the three 1 $\mathrm{m}^{2}$ quadrats in each plot in 2014 and 2015. Flower cover was assessed at the end of June each year.

\begin{tabular}{|c|c|c|c|c|c|c|c|c|c|c|c|c|c|c|c|}
\hline & $\mathrm{C} 1$ & $\mathrm{C} 2$ & $\mathrm{C} 3$ & VL1 & VL2 & VL3 & L1 & L2 & L3 & $\mathrm{H} 1$ & $\mathrm{H} 2$ & $\mathrm{H} 3$ & $\mathrm{VH} 1$ & $\mathrm{VH} 2$ & VH3 \\
\hline \multicolumn{16}{|l|}{2014} \\
\hline Realized FD (Rao's index) & 0.075 & 0.053 & 0.012 & 0.006 & 0.006 & 0.006 & 0.044 & 0.046 & 0.048 & 0.093 & 0.020 & 0.058 & 0.055 & 0.115 & 0.112 \\
\hline \multicolumn{16}{|l|}{ Flower cover (\%) } \\
\hline Achillea millefolium & 0.67 & 0 & 0.67 & 9.67 & 11.67 & 4.67 & 5 & 14.33 & 12.67 & 1 & 15 & 9.67 & 8.33 & 3.67 & 1.33 \\
\hline Aethusa cynapium & 0 & 0 & 0 & 0 & 0 & 0 & 0 & 0 & 0.33 & 0 & 0 & 0 & 0 & 0 & 0 \\
\hline Capsella bursa-pastoris & 0.33 & 0 & 0 & 0 & 0 & 0 & 0 & 0 & 0 & 0 & 0 & 0 & 0 & 0 & 0 \\
\hline Cichorium intybus & 0 & 0 & 0 & 0.67 & 0 & 0 & 0 & 0 & 0 & 0 & 0 & 0 & 0 & 0 & 0 \\
\hline Cirsium arvense & 1 & 5.33 & 0.33 & 0 & 0 & 0.67 & 0.67 & 0 & 0.67 & 0 & 0 & 0 & 0 & 0 & 0.67 \\
\hline Conyza canadensis & 0 & 0 & 0 & 0 & 0 & 0 & 0 & 0 & 0 & 0 & 0.33 & 0 & 0 & 0 & 0 \\
\hline Crepis biennis & 0 & 0 & 0 & 0 & 0 & 0 & 6 & 1.33 & 3.67 & 0 & 0 & 0 & 0.67 & 0 & 0 \\
\hline Galium verum & 0.33 & 0 & 0 & 2 & 2 & 3.33 & 1.33 & 1 & 3.33 & 0 & 0.33 & 0 & 0 & 0 & 0 \\
\hline Geranium pyrenaicum & 0 & 0 & 0 & 0 & 0 & 0 & 0.33 & 0 & 0 & 4.67 & 0.33 & 0.67 & 0 & 0 & 0 \\
\hline Hypochaeris radicata & 0.67 & 0 & 0 & 0 & 0 & 0 & 11.33 & 13 & 20 & 0 & 0.33 & 0 & 0 & 0 & 0 \\
\hline Knautia arvensis & 0 & 0 & 0 & 0 & 0 & 0.33 & 0.33 & 0 & 0.33 & 0 & 0 & 0 & 0 & 0 & 0 \\
\hline Leontodon hispidus & 0 & 0 & 0 & 0 & 0 & 0 & 0 & 1 & 1.67 & 0 & 0 & 0 & 0 & 0 & 0 \\
\hline Leucanthemum vulgare & 0.67 & 0 & 0 & 56.67 & 56.67 & 63.33 & 0 & 1 & 2 & 3.67 & 38.33 & 45 & 0 & 1 & 3 \\
\hline Lotus corniculatus & 0 & 0 & 0 & 0 & 0 & 0 & 0 & 0 & 0 & 0 & 0 & 0 & 33.33 & 1.33 & 0.67 \\
\hline Malva moschata & 0 & 0 & 0 & 0 & 0.33 & 0 & 0 & 0 & 0 & 0 & 0 & 1.33 & 2.33 & 1.33 & 4.33 \\
\hline Matricaria recutita & 1 & 0.33 & 0.33 & 1 & 0 & 0 & 0 & 0 & 0 & 0.33 & 0 & 0 & 2.67 & 0 & 1.67 \\
\hline Medicago Iupulina & 0 & 0 & 0 & 0 & 0 & 0 & 0 & 0 & 0 & 0 & 0 & 0 & 2.33 & 1 & 1.33 \\
\hline Origanum vulgare & 0 & 0 & 0 & 0 & 0 & 0 & 0 & 0 & 0 & 0 & 0.67 & 0 & 0 & 0 & 0 \\
\hline Prunella vulgaris & 0 & 0 & 0 & 0 & 0 & 0 & 0 & 0 & 0 & 0 & 1.67 & 8 & 1.33 & 2 & 1 \\
\hline Sinapis alba & 1.33 & 1.33 & 0 & 0 & 0 & 0 & 0 & 0 & 0 & 0 & 0 & 0 & 0 & 5 & 0 \\
\hline Trifolium repense & 0 & 0 & 0 & 0 & 0 & 0 & 0 & 0 & 0 & 0 & 0 & 0 & 0 & 0.33 & 0 \\
\hline
\end{tabular}

2015

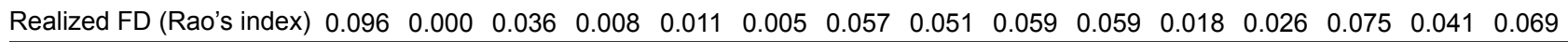

\begin{tabular}{|c|c|c|c|c|c|c|c|c|c|c|c|c|c|c|c|}
\hline \multicolumn{16}{|l|}{ Flower cover (\%) } \\
\hline Achillea millefolium & 1 & 0 & 1.33 & 9.67 & 20 & 8.67 & 13.67 & 24 & 20.33 & 5.33 & 33.33 & 22.67 & 20 & 38.33 & 27.67 \\
\hline Silene latifolia & 0 & 0 & 0 & 0 & 0 & 0 & 0 & 0 & 0 & 0 & 0 & 0.33 & 0 & 0 & 0 \\
\hline Cirsium arvense & 1.67 & 10.67 & 0.67 & 0 & 0 & 2 & 1.33 & 0 & 0.67 & 1 & 0.33 & 0.33 & 1 & 2 & 0.67 \\
\hline Crepis biennis & 0 & 0 & 0 & 0 & 0 & 0 & 0.67 & 0.67 & 0 & 0 & 0 & 0 & 0 & 0 & 0 \\
\hline Galium verum & 0.33 & 0 & 0.33 & 2.33 & 3.33 & 1.67 & 1.33 & 1 & 4 & 0 & 0 & 0 & 0.33 & 0 & 0 \\
\hline Geranium pyrenaicum & 0 & 0 & 0 & 0 & 0 & 0 & 0.67 & 0 & 0 & 5.33 & 0.33 & 0 & 0 & 0 & 0 \\
\hline Hypochaeris radicata & 0.33 & 0 & 0 & 0 & 0.33 & 0 & 3.33 & 22.33 & 8 & 0 & 0.33 & 0 & 0 & 0 & 0 \\
\hline Knautia arvensis & 0 & 0 & 0 & 0 & 0 & 0.33 & 0.33 & 0 & 0 & 0 & 0 & 0 & 0 & 0 & 0 \\
\hline Leontodon hispidus & 0 & 0 & 0 & 0 & 0 & 0 & 1 & 2.67 & 8.33 & 0 & 1.33 & 1 & 0 & 0 & 0 \\
\hline Leucanthemum vulgare & 1.67 & 0 & 0 & 71.67 & 80 & 96 & 0 & 1.33 & 8 & 19.33 & 68.33 & 51.67 & 0 & 0.33 & 6.67 \\
\hline Lotus corniculatus & 0 & 0 & 0 & 0 & 0 & 0 & 0 & 0 & 0 & 0 & 0 & 0 & 0.67 & 0 & 0 \\
\hline Malva moschata & 0 & 0 & 0 & 0 & 0 & 0 & 0 & 0 & 0.67 & 0 & 0.33 & 0.33 & 1.67 & 1.33 & 4.33 \\
\hline Malva sylvestris & 0 & 0 & 0 & 0 & 0 & 0 & 0 & 0 & 0.33 & 0 & 0 & 0 & 0 & 0 & 0 \\
\hline Medicago Iupulina & 0 & 0 & 0 & 0 & 0 & 0 & 0 & 0 & 0 & 0 & 0 & 0 & 0.33 & 0 & 0 \\
\hline Plantago major & 0.33 & 0 & 0 & 0 & 0 & 0 & 0 & 0 & 0 & 0 & 0 & 0 & 0 & 0 & 0 \\
\hline Prunella vulgaris & 1.33 & 0 & 0 & 0.33 & 0.67 & 0 & 0 & 0 & 0 & 0 & 1.67 & 2.67 & 2 & 2 & 1.67 \\
\hline Rumex obtusifolius & 0 & 0 & 0 & 3.33 & 0 & 0 & 0 & 1.33 & 0 & 0 & 0 & 0 & 10.33 & 0.67 & 0 \\
\hline Rumex crispus & 2 & 0 & 0 & 0 & 0 & 0 & 0 & 0 & 0 & 0 & 0 & 0 & 0.67 & 0 & 0 \\
\hline Sonchus sp. & 0 & 0 & 0 & 0.33 & 0 & 0 & 0.67 & 0 & 0 & 0 & 0 & 0 & 0 & 0 & 0 \\
\hline Trifolium sp. & 0 & 0 & 0 & 0.33 & 0 & 0 & 0 & 0 & 0 & 0 & 0 & 0 & 0 & 0.67 & 0 \\
\hline
\end{tabular}

bles 3-4). Ladybeetles were the most abundant predators in both years, especially in 2014 , followed by hoverflies and lacewings (total abundance is presented in Table 3). Equal species richness was recorded for ladybeetles and hoverflies in 2014 (i.e., four species); however, hoverfly species richness was higher in 2015 (i.e. five and three species respectively, Table 3). During this two year experiment, only one species of lacewing was recorded.

\section{Effect of sown mixtures and realized functional diversity on aphid predators}

Only ladybeetle abundance was significantly associated with the mixtures sown (Table 4). As the interaction be- tween mixture and year effects was also significant, annual analyses showed that mixtures had a nearly significant effect in $2014\left(\mathrm{df}=4 ; \chi^{2}=9.4 ; \mathrm{p}\right.$-value $\left.=0.052\right)$ and a significant effect in $2015\left(\mathrm{df}=4 ; \chi^{2}=12.4\right.$; $\mathrm{p}$-value $\left.=0.014\right)$. The mixtures had no significant effect on the sums of predators, lacewings and hoverflies and their species richness (Table 4). In 2014 , ladybeetles were the most numerous in VL, L and $\mathrm{H}$ mixtures, whereas they were the least abundant in L and VH mixtures in 2015 (Fig. 2). Neither insect abundance (i.e., sum of predators, as well as every family separately) nor their species richness was significantly affected by the realized FD in either 2014 or 2015 (Table 5). 
Table 3. Summed abundance of every aphid predator species trapped in each mixture (over a seven-week period from May to June in both years, three repetitions per mixture, one yellow pan-trap per repetition, which was emptied and refilled every week).

\begin{tabular}{|c|c|c|c|c|c|c|c|c|c|c|c|c|c|}
\hline & \multicolumn{6}{|c|}{2014} & \multicolumn{6}{|c|}{2015} & \multirow{2}{*}{$\begin{array}{c}\text { 2014-2015 } \\
\text { Total }\end{array}$} \\
\hline & $\mathrm{C}$ & VL & $\mathrm{L}$ & $\mathrm{H}$ & $\mathrm{VH}$ & Total & C & VL & $\mathrm{L}$ & $\mathrm{H}$ & $\mathrm{VH}$ & Total & \\
\hline Lacewings & 4 & 5 & 3 & 2 & 1 & 15 & 1 & 2 & 3 & 2 & 1 & 9 & 24 \\
\hline Chrysoperla carnae (Stephens, 1836) & 4 & 5 & 3 & 2 & 1 & 15 & 1 & 2 & 3 & 2 & 1 & 9 & 24 \\
\hline Ladybeetles & 15 & 31 & 23 & 30 & 14 & 113 & 5 & 6 & - & 9 & 3 & 23 & 136 \\
\hline Coccinella 7 punctata (Linnaeus, 1758) & - & 8 & 3 & 4 & - & 15 & 1 & 4 & - & 3 & 1 & 9 & 24 \\
\hline Harmonia 4 punctata (Pontoppidan, 1763) & - & - & - & - & - & - & - & - & - & 1 & - & 1 & 1 \\
\hline Harmonia axyridis (Pallas, 1773) & 7 & 11 & 9 & 12 & 8 & 47 & - & - & - & - & - & - & 47 \\
\hline Propylea 14 punctata (Linnaeus, 1758) & 9 & 12 & 10 & 14 & 5 & 50 & 4 & 2 & - & 5 & 2 & 13 & 63 \\
\hline Tytthaspis 16 punctata (Linnaeus, 1761) & - & - & 1 & - & 1 & 2 & - & - & - & - & - & - & 2 \\
\hline Hoverflies & 6 & 6 & 9 & 6 & 6 & 33 & 6 & 1 & 2 & 6 & 4 & 19 & 52 \\
\hline Episyrphus balteatus (De Geer, 1776) & 5 & 5 & 8 & 4 & 4 & 26 & 1 & 1 & - & - & 3 & 5 & 31 \\
\hline Eupeodes corollae (Fabricius, 1794) & - & 1 & 1 & - & 1 & 3 & 1 & - & 2 & 1 & - & 4 & 7 \\
\hline Melanostoma mellinum (Linnaeus, 1758) & - & - & - & 2 & - & 2 & - & - & - & 2 & - & 2 & 4 \\
\hline Platycheirus manicatus (Meigen, 1822) & - & - & - & - & - & - & - & - & - & 1 & - & 1 & 1 \\
\hline Sphaerophoria scripta (Linnaeus, 1758) & - & - & - & - & - & - & 4 & - & - & 2 & 1 & 7 & 7 \\
\hline Syrphus ribesii (Linnaeus, 1758) & - & - & - & - & 1 & 1 & - & - & - & - & - & - & 1 \\
\hline Total & 25 & 42 & 35 & 38 & 21 & 161 & 12 & 9 & 5 & 17 & 8 & 51 & 212 \\
\hline
\end{tabular}

"-" indicates that no individuals of these species were trapped.

\section{DISCUSSION}

Our study indicates that a high abundance and richness of flower visiting aphid predators is not necessarily associated with a high FD of flower mixtures. Only ladybeetles, which made up the majority of the predators trapped in both years, were affected by the sown mixtures. Ladybeetles were mostly trapped in plots where the FD of the mixture was very low or intermediate at sowing, especially in 2014.

A surprisingly low number of predators was trapped. In the case of hoverflies, we trapped on average 30 times

Table 4. Effect of mixtures sown (C, VL, L, H, VH) and years (2014, 2015), and their interaction, on the abundance and species richness of predators. Signs of estimates were retrieved from the selected models when significant, "-" means that the values for 2015 were lower than those for 2014. Degree of freedom (df), $x^{2}$ - and $p$-values were obtained from the likelihood ratio tests performed on the selected model. ${ }^{*} \mathrm{P}<0.05 ;{ }^{* * *} \mathrm{P}<0.001$.

\begin{tabular}{|c|c|c|c|c|}
\hline & Estimate & $\mathrm{df}$ & $x^{2}$ & p-value \\
\hline \multicolumn{5}{|l|}{ Abundance } \\
\hline \multicolumn{5}{|l|}{ Predators } \\
\hline Mixture & & 4 & 7.75 & 0.101 \\
\hline Year & - & 1 & 45.6 & $<0.001^{* * *}$ \\
\hline FD:Year & & 4 & 6.18 & 0.186 \\
\hline \multicolumn{5}{|l|}{ Lacewings } \\
\hline Mixture & & 4 & 3.41 & 0.476 \\
\hline Year & & 1 & 1.52 & 0.212 \\
\hline FD:Year & & 4 & 1.74 & 0.784 \\
\hline \multicolumn{5}{|l|}{ Ladybeetles } \\
\hline Mixture & & 4 & 12.2 & 0.016 * \\
\hline Year & - & 1 & 55.3 & $<0.001^{* * *}$ \\
\hline FD:Year & & 4 & 9.82 & 0.044 * \\
\hline \multicolumn{5}{|l|}{ Hoverflies } \\
\hline Mixture & & 4 & 1.12 & 0.891 \\
\hline Year & & 1 & 1.99 & 0.158 \\
\hline FD:Year & & 4 & 2.74 & 0.602 \\
\hline \multicolumn{5}{|c|}{ Species richness } \\
\hline \multicolumn{5}{|c|}{ Predators } \\
\hline Mixture & & 4 & 7.12 & 0.130 \\
\hline Year & - & 1 & 33.7 & $<0.001^{* * *}$ \\
\hline FD:Year & & 4 & 5.67 & 0.225 \\
\hline
\end{tabular}

more per week per trap in the crops growing adjacent to the WFS in 2015 (Hatt et al., 2017) while Tschumi et al. (2016) trapped on average 20 times more per week per trap in WFS adjacent to potato crops in June and July in Switzerland. A reason for this might be that hoverfly abundance often peaks in July in such regions, as was the case in 2015 in adjacent crops (Hatt et al., 2017). In the present experiment, insects were trapped in the WFS only up to the end of June. As for ladybeetles, a slightly higher number than recorded in these previous studies was trapped in 2014, but three times less was recorded in 2015. Indeed, insect abundance differed in the two years of the study. The higher abundance of predators, especially ladybeetles, in 2014 might be due to the early summer in that year, favouring greater insect occurrence in early spring compared to 2015. In addition, other studies conducted in the same region report a very low density of ladybeetles in 2015, indicating that their abundance was low that year in the region of Gembloux (Fassotte, 2016; Hatt et al., 2017). Similar annual variability in ladybeetle abundance is reported in Belgium (Vandereycken et al., 2013).

The results recorded for the effect of FD contradicted our hypothesis. We expected the abundance and richness of natural enemies to be positively associated with FD,

Table 5. Effect of realized functional diversity (Rao's index) on predator abundance and species richness of predators in 2014 and 2015. Signs of estimates were retrieved from the selected models. Degree of freedom (df), $x^{2}$ - and $p$-values were obtained from the likelihood ratio tests performed on the selected models.

\begin{tabular}{|c|c|c|c|c|c|c|c|}
\hline & \multicolumn{4}{|c|}{2014} & \multicolumn{3}{|c|}{2015} \\
\hline & Estimate & & $x^{2}$ & $\overline{p \text {-value }}$ & Estimate $\mathrm{d}$ & If $x^{2}$ & $\overline{p \text {-value }}$ \\
\hline \multicolumn{8}{|l|}{ Abundance } \\
\hline Predators & - & 1 & 2.78 & 0.096 & - & 10.04 & 0.846 \\
\hline Lacewings & - & 1 & 2.18 & 0.140 & - & 10.12 & 0.73 \\
\hline Ladybeetles & - & 1 & 2.93 & 0.089 & - & 11.70 & 0.192 \\
\hline Hoverflies & - & 1 & $<0.01$ & 1 & + & 12.09 & 0.148 \\
\hline \multicolumn{8}{|l|}{ Diversity } \\
\hline $\begin{array}{l}\text { Species } \\
\text { richness }\end{array}$ & - & 1 & 2.75 & 0.097 & - & 10.63 & 0.428 \\
\hline
\end{tabular}


2014 2015
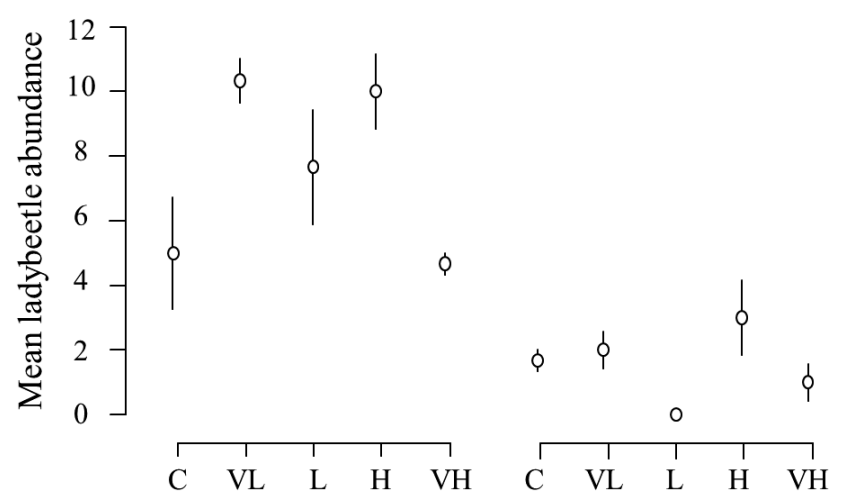

Fig. 2. Mean (summed abundance recorded during seven weeks of trapping each year divided by the three repetitions \pm SEM) ladybeetle abundance in each mixture sown, based on their functional diversity at sowing: $\mathrm{C}-$ control, $\mathrm{VL}-$ very low, $\mathrm{L}-$ low, $\mathrm{H}$ - high, $\mathrm{VH}$ - very high.

because these predators have different nutritional requirements and might react differently to different flower traits at different times. However, our findings are consistent with Balzan et al. (2014, 2016), who report that FD had no effect on the abundance of flower visiting natural enemies. Furthermore, these authors report that mixtures with intermediary FD support a higher natural enemy richness. Balzan et al. $(2014,2016)$ increased FD by increasing the diversity of flower corolla types, which determines the ability of natural enemies to benefit from flower nectar (Vattala et al., 2006; Van Rijn \& Wäckers, 2016). Insect abundance and diversity recorded in this study, however is not associated with FD based on seven traits. Balzan et al. $(2014,2016)$ suggest that the presence of certain species of plants, particularly those attractive to natural enemies (i.e., Apiaceae spp. in their case), might mask the effect of FD on flower visitors. This might also have affected our results, especially as some flowering species covered a large surface area in some plots, whereas others that were sown were not even recorded (Table 2).

There are several explanations for the unequal establishment of different species of plants, despite similar seed weights being sown. For instance, competition for space and resources might result in the establishment of the most competitive species. Alternatively, the conventional farming practices used in the field before the experiment (especially the application of nitrogen fertilisers) might have favoured the most productive species, which limited the establishment of diversified mixtures (Pywell et al., 2002). In our experiment, the Asteraceae Leucanthemum vulgare was the most abundant species in VL and $\mathrm{H}$ mixtures (Table 2). The high abundance of this species, compared to others, may account for the lower than expected values of realized FD in $\mathrm{H}$ and the low values in VL plots. However, most of the predators trapped, especially ladybeetles, were trapped in the $\mathrm{H}$ and VL plots. Leucanthemum vulgare is typically visited by hoverflies, ladybeetles and lacewings (Ricci et al., 2005; Carrié et al., 2012; Wäckers \& Van Rijn, 2012), because it is a rich source of nectar and pollen (Brodie et al., 2015). This resource might be of particular benefit to ladybeetles, for which pollen is one its most nutritious nonprey food sources, enabling them to complete their development and survive when prey are scarce (Berkvens et al., 2008; Lundgren, 2009).

Adult hoverflies exclusively feed on flowers, with pollen providing a source of proteins that directly influence their fecundity, while nectar is a source of sugars, providing energy and increasing their longevity and foraging capacity (Laubertie et al., 2012; Van Rijn et al., 2013). Thus, any flower that was abundant in the mixtures and produced nectar (i.e. flowers with shallow florets, because hoverflies have a short proboscis; Van Rijn \& Wäckers, 2016) and pollen are likely to be attractive. For instance, the Asteraceae, Achillea millefolium, is typically visited by hoverflies (Salveter, 1998; Tooker et al., 2006; Carrié et al., 2012) and enhances their longevity (Van Rijn \& Wäckers, 2016). In our study, A. millefolium was present in every flower mixture, and was quite abundant in most plots (Table 2). The presence of this species might have resulted in hoverflies being equally distributed across the different treatments. Moreover, ladybeetles and hoverflies are sensitive to colour, especially yellow (Sutherland et al., 1999; Mondor et al., 2000). Hoverflies are also sensitive to flowers with a contrasting UV-pattern (Koski \& Ashman, 2014). Some species with these traits might have been attractive. For instance, Hypochaeris radicata was quite abundant in L mixtures, especially in 2014, and might have attracted hoverflies, resulting in their being slightly (but not significantly) more numerous in plots with these than other mixtures.

Lacewings were less abundant than other predators in both years. They might also have benefited from a large variety of flowers in the strips, as they are considered to be opportunistic (Villenave et al., 2006). In addition, some spontaneous weeds, such as $C$. arvense and $R$. obtusifolius (the most abundant spontaneous plants listed in several plots), might have attracted predators, as they often host aphids that are prey for ladybeetle adults and the larvae of all three predators studied (Salveter, 1998). This phenomenon might also explain why some individuals were trapped in the control plots, even when few floral resources were available but with the values of the functional traits differed enough to result in higher than expected values of realized FD.

The presence of prey in adjacent crops might also have attracted natural enemies out of the flower strips, potentially explaining their generally low abundance in the mixtures. Indeed, hoverfly adults for instance search for aphid colonies in which to lay their eggs after having fed on flowers (Almohamad et al., 2009). While further analyses are needed to confirm such a hypothesis, a higher abundance of natural enemies in adjacent crops than in WFS, would enhance biological pest control. Despite the higher FD of $\mathrm{VH}$ mixtures at sowing, and to some extent in 2014 and 2015 (Table 2), the low attraction of the WFS to natural enemies might also be explained by the limited establishment of some of the species sown. The cover of 
sown flower species in the quadrats was low (except for $A$. millefolium, which was also abundant in other mixtures) and, some sown species, like Lythrum salicaria, were not even recorded in the quadrats (Table 2). Moreover, some of the plant species that established successfully could a priori not provide food for hoverflies, ladybeetles or lacewings, because of their flower morphology. This is the case for plants of both Fabaceae and Malvaceae, which have a corolla that is too deep for e.g. hoverflies to access their nectar (Wäckers \& Van Rijn, 2012).

The non-significant correlations between the sown and realized FD indicate that it is difficult to obtain a certain realized FD by sowing flower mixtures. This may be due to various factors such as the presence of spontaneous species, the better development of the most productive and competitive, and the non-development of some sown species. Considering the optimal growing conditions (e.g. exposure to sun, humidity, soil disturbance) for the different species on the one hand, and better balancing of the number of seeds between the different species by also considering their productivity and competitiveness (and not only considering their weight as in this study) on the other hand, may result in more diversified mixtures. Moreover, rather than relying on mixture FD, sowing flower species that are known to support natural enemies might enhance their presence in WFS, and even favour pest control in adjacent crops. This is the "pick and mix" approach developed by Wäckers \& Van Rijn (2012) and successfully tested in the field by Tschumi et al. $(2014,2015,2016)$. Nevertheless, WFS have to provide multiple ecosystem services, including pollination, and participate in the conservation of insect species that are endangered in agricultural landscapes (Ekroos et al., 2014; Batáry et al., 2015). Within this context, a higher diversity of arthropods could potentially occur in flower mixtures with a high FD. Indeed, Balzan et al. (2014) report that the abundance of wild bees (Hymenoptera) increases with FD. Depending on the objectives assigned to WFS (i.e. enhancing pest control, pollination, conservation, or all of these combined), different strategies could be used when formulating flower mixtures.

Within an agricultural context, sowing WFS is proposed to enhance biodiversity conservation and ecosystem services, with doubts being raised about whether they will be a source of pests infesting adjacent crops (Frank, 1998; Hatt et al., 2015; Tscharntke et al., 2016). Moreover, it is worth establishing the threshold at which increasing the mixture of FD also improves its attraction for predators and shelters pests. For instance, aphids use visual and olfactory cues to locate host plants (Döring, 2014). Thus, increasing plant functional diversity might increase the chance of including more colours, UV patterns and odours that are attractive to aphids. It is also possible, a higher diversity of trait values might confuse aphids. For instance, when a high diversity of colours is present, the attractive ones might be masked. In parallel, if a large variety of odours is present, it might not be possible to distinguish attractive cues. This effect of diversified plant systems was first theorised by Root (1973) in the Resource concentration hypothesis. This suggests that diversified cropping systems (e.g. intercropping), or, in the present case, diversified flower strips, might be less attractive to pests than monospecific systems (Letourneau et al., 2011; Lopes et al., 2016).

The present study investigated an array of traits; however, the selection was not exhaustive. Other traits could have been chosen; for instance, traits related to the abundance and quality of nectar and pollen (rather than just availability, as used here in the context of "flower type" based on the classification of Müller, 1881) or the profile of semiochemical volatiles emitted by flowers. Indeed, flower visiting insects, particularly aphid predators, respond to nectar and pollen abundance and quality, as well as odour (Laubertie et al., 2006; Adedipe \& Park, 2010; Laubertie et al., 2012). Thus, it is necessary to screen a variety of flower species for these traits and establish their ability to attract and support aphid predators, in order to advance our knowledge in this field of research. As the value of the FD being tested depends on the chosen traits, further field-based research assessing different mixtures based on several other traits should be implemented, with the objective of enhancing the ability of WFS to deliver multiple ecosystem services in agriculture.

ACKNOWLEDGMENTS. The authors thank the Experimental Farm of Gembloux Agro-Bio Tech (University of Liège) for providing technical support, F. Van De Meutter (The Research Institute for Nature and Forest - INBO, Belgium) for verifying hoverfly identifications, the TRY initiative on plant traits (http://www. try-db.org) for providing the data on flower traits, and the two anonymous reviewers whose accurate comments and suggestions improved the manuscript. The Belgian National Fund for Scientific Research (FNRS) awarded FRIAs (Fonds pour la Recherche en Industrie et Agronomie) PhD scholarship to T. Lopes. S. Hatt, R. Uyttenbroeck, and this study in general was funded by CARE AgricultureIsLife (University of Liège) and the Chinese Opening Fund of State Key Laboratory for Biology of Plant Diseases and Insect Pests (SKLOF201601).

\section{REFERENCES}

Adedipe F. \& PARK Y.-L. 2010: Visual and olfactory preference of Harmonia axyridis (Coleoptera: Coccinellidae) adults to various companion plants. - J. Asia-Pac. Entomol. 13: 316-323.

Almohamad R., Verheggen F. \& Haubruge É. 2009: Searching and oviposition behavior of aphidophagous hoverflies (Diptera: Syrphidae): a review. - Biotechnol. Agron. Soc. Environ. 13: 467-481.

Baldi I., Cordier S., Coumoul X., Elbaz A., Gamet-Payrastre L., Le Bailly P., Multigner L., Rahmani R., Spinosi J. \& Van Maele-Fabry G. 2013: Pesticides: Effets sur la Santé. Institut national de la santé et de la recherche médicale, Paris, 1002 pp.

Balzan M.V., Bocci G. \& Moonen A.-C. 2014: Augmenting flower trait diversity in wildflower strips to optimise the conservation of arthropod functional groups for multiple agroecosystem services. - J. Insect Conserv. 18: 713-728.

Balzan M.V., Bocci G. \& Moonen A.-C. 2016: Utilisation of plant functional diversity in wildflower strips for the delivery of multiple agroecosystem services. - Entomol. Exp. Appl. 158: 304-319.

Barbosa P.A. 1998: Conservation Biological Control. Academic Press, San Diego, 420 pp. 
Batáry P., Dicks L.V., Kleijn D. \& Sunderland W.J. 2015: The role of agri-environment schemes in conservation and environmental management. - Conserv. Biol. 29: 1006-1016.

Bates D., Maechler M., Bolker B. \& Walker S. 2014: Ime4: Linear mixed-effects models using Eigen and S4. R package. URL: http://CRAN.R-project.org/package=lme4

Berkvens N., Bonte J., Berkvens D., Deforce K., Tirry L. \& De ClercQ P. 2008: Pollen as an alternative food for Harmonia axyridis. - BioControl 53: 201-210.

BotTA-DukÁt Z. 2005: Rao's quadratic entropy as a measure of functional diversity based on multiple traits. - J. Veg. Sci. 16: 533-540.

Brodie B.S., Smith M.A., Lawrence J. \& Gries G. 2015: Effects of floral scent, color and pollen on foraging decisions and oocyte development of common green bottle flies. - PLOS ONE 10(12): e0145055, $15 \mathrm{pp}$.

Campbell A.J., Biesmeijer J.C., Varma V. \& Wäckers F.L. 2012: Realising multiple ecosystem services based on the response of three beneficial insect groups to floral traits and trait diversity. - Basic Appl. Ecol. 13: 363-370.

CAmpbell D.R., Bischoff M., Lord J.M. \& Robertson A.W. 2010: Flower color influences insect visitation in alpine New Zealand. - Ecology 91: 2638-2649.

Carrié R.J.G., George D.R. \& Wäckers F.L. 2012: Selection of floral resources to optimise conservation of agriculturallyfunctional insect groups. - J. Insect Conserv. 16: 635-640.

Chittka L., Shmida A., Troje N. \& Menzel R. 1994: Ultraviolet as a component of flower reflections, and the colour perception of Hymenoptera. - Vision Res. 34: 1489-1508.

Colley M.R. \& LunA J.M. 2000: Relative attractiveness of potential beneficial insectary plants to aphidophagous hoverflies (Diptera: Syrphidae). — Environ. Entomol. 29: 1054-1059.

Devine G.J. \& Furlong M.J. 2007: Insecticide use: Contexts and ecological consequences. - Agric. Hum. Values 24: 281-306.

DíAz S. \& CABIDO M. 2001: Vive la différence: plant functional diversity matters to ecosystem processes. - Trends Ecol. Evol. 16: $646-655$.

DörING T.F. 2014: How aphids find their host plants, and how they don't. - Ann. Appl. Biol. 165: 3-26.

DraY S. \& Dufour A.B. 2007: The ade4 package: implementing the duality diagram for ecologists. - J. Stat. Softw. 22(4): $1-20$.

Ekroos J., Olsson O., RundlöF M., WÄtzold F. \& SMith H.G. 2014: Optimizing agri-environment schemes for biodiversity, ecosystem services or both? - Biol. Conserv. 172: 65-71.

European Commission 2005: Agri-environment Measures. Overview on General Principles, Types of Measures and Application. European Commission, Directorate General for Agriculture and Rural Development, Brussels, 24 pp.

Evans E.W. 2003: Searching and reproductive behaviour of female aphidophagous ladybirds (Coleoptera: Coccinellidae): a review. - Eur. J. Entomol. 100: 1-10.

Fassotte B. 2016: Sexual Attraction in Lady Beetles: Fundamentals and Applications. PhD Thesis, University of Liège - Gembloux Agro-Bio Tech, Gembloux, 160 pp.

FIEDLER A.K. \& LANDIS D.A. 2007a: Attractiveness of Michigan native plants to arthropod natural enemies and herbivores. Environ. Entomol. 36: 751-765.

FiedLeR A.K. \& LANDIS D.A. 2007b: Plant characteristics associated with natural enemy abundance at Michigan native plants. —Environ. Entomol. 36: 878-886.

Fontaine C., Dajoz I., Meriguet J. \& Loreau M. 2006: Functional diversity of plant-pollinator interaction webs enhances the persistence of plant communities. - PLoS Biol. 4: 129-135.
Foster S.P., Devine G.J. \& Devonshire A.L. 2007: Insecticide resistance. In Van Emden H.F. \& Harrington R. (eds): Aphids Crop Pests. CABI, Cambridge, MA, pp. 261-286.

FrANK T. 1998: The role of different slug species in damage to oilseed rape bordering on sown wildflower strips. - Ann. Appl. Biol. 133: 483-493.

HaAland C., Naisbit R.E. \& Bersier L.-F. 2011: Sown wildflower strips for insect conservation: a review. - Insect Conserv. Divers. 4: 60-80.

Hatt S., Uyttenbroeck R., Lopes T., Paul A., Danthine S., Bodson B., Piqueray J., Monty A. \& Francis F. 2015: Do wildflower strips favor insect pest populations at field margins? Agric. Agric. Sci. Procedia 6: 30-37.

Hatt S., Lopes T., Boeraeve F., Chen J. \& Francis F. 2017: Pest regulation and support of natural enemies in agriculture: experimental evidence of within field wildflower strips. - Ecol. Eng. 98: 240-245.

Hodge I., Hauck J. \& Bonn A. 2015: The alignment of agricultural and nature conservation policies in the European Union. - Conserv. Biol. 29: 996-1005.

Holland J.M., Bianchi F.J.J.A., Entling M.H., Moonen A.C., Smith B.M. \& JeAnNeret P. 2016: Structure, function and management of semi-natural habitats for conservation biological control: a review of European studies. - Pest Manag. Sci. 72: 1638-1651.

Kattge J., Díaz S., Lavorel S., Prentice I.C., Leadley P., Bönisch G., Garnier E., Westoby M., Reich P.B., Wright I.J. et al. 2011: TRY - a global database of plant traits. - Glob. Change Biol. 17: 2905-2935.

Koski M.H. \& Ashman T.-L. 2014: Dissecting pollinator responses to a ubiquitous ultraviolet floral pattern in the wild. -Funct. Ecol. 28: 868-877.

Lambinon J., Delvosalle L. \& Duvigneaud J. 2004: Nouvelle Flore de Belgique, du Grand-Duché de Luxembourg, du Nord de la France et des Régions Voisines. 5th ed. Jardin Botanique National de Belgique, Meise, $1167 \mathrm{pp}$.

Lambinon J., De Langhe J.-E., Delvosalle L. \& Duvigneaud J. 2008: Flora van Belgie, het Groothertogdom Luxemburg, Noord-Frankrijk en de Aangrenzende Gebieden. Nationale Plantentuin van België, Meise, $1091 \mathrm{pp}$.

Landis D.A., Wratten S.D. \& GurR G.M. 2000: Habitat management to conserve natural enemies of arthropod pests in agriculture. - Annu. Rev. Entomol. 45: 175-201.

Laubertie E.A., Wratten S.D. \& Sedcole J.R. 2006: The role of odour and visual cues in the pan-trap catching of hoverflies (Diptera: Syrphidae). — Ann. Appl. Biol. 148: 173-178.

Laubertie E.A., Wratten S.D. \& Hemptinne J.-L. 2012: The contribution of potential beneficial insectary plant species to adult hoverfly (Diptera: Syrphidae) fitness. - Biol. Contr. 61: 1-6.

Letourneau D.K., Armbrecht I., Rivera B.S., Lerma J.M., Carmona E.J., Daza M.C., Escobar S., Galindo V., Gutiérrez C., LÓPEZ S.D. ET AL. 2011: Does plant diversity benefit agroecosystems? A synthetic review. - Ecol. Appl. 21: 9-21.

Lopes T., Hatt S., Xu Q., Chen J., Liu Y. \& Francis F. 2016: Wheat (Triticum aestivum L.)-based intercropping systems for biological pest control: a review. - Pest Manag. Sci. 72: 2193-2202.

Lu Z.-X., Zhu P.-Y., Gurr G.M., Zheng X.-S., Read D.M.Y., Heong K.-L., Yang Y.-J. \& Xu H.-X. 2014: Mechanisms for flowering plants to benefit arthropod natural enemies of insect pests: Prospects for enhanced use in agriculture. - Insect Sci. 21: $1-12$.

LUNDGREN J.G. 2009: Nutritional aspects of non-prey foods in the life histories of predaceous Coccinellidae. - Biol. Contr. 51: 294-305. 
McKenzie A.J., Emery S.B., Franks J.R. \& Whittingham M.J. 2013: Landscape-scale conservation: collaborative agri-environment schemes could benefit both biodiversity and ecosystem services, but will farmers be willing to participate? $-J$. Appl. Ecol. 50: 1274-1280.

Miller N., Al Dobai S., Legaspi J. \& Sivinski J. 2013: Estimating attraction of Syrphidae (Diptera) to flowering plants with interception traps. - Biocontr. Sci. Technol. 23: 1040-1052.

Mondor E.B. \& Warren J.L. 2000: Unconditioned and conditioned responses to colour in the predatory coccinellid, Harmonia axyridis (Coleoptera: Coccinellidae). — Eur. J. Entomol. 97: 463-467.

MÜlLER H. 1881: Alpenblumen, ihre Befruchtung durch Insekten und ihre Anpassungen an dieselben. Wilhelm Engelmann, Leipzig, $612 \mathrm{pp}$.

Pywell R.F., Bullock J.M., Hopkins A., Walker K.J., Sparks T.H., Burke M.J.W. \& Peel S. 2002: Restoration of speciesrich grassland on arable land: assessing the limiting processes using a multi-site experiment. - J. Appl. Ecol. 39: 294-309.

R Core Team 2013: R: A Language and Environment for Statistical Computing. R Foundation for Statistical Computing, Vienna.

Rand T.A., Tylianakis J.M. \& TscharntKe T. 2006: Spillover edge effects: the dispersal of agriculturally subsidized insect natural enemies into adjacent natural habitats. - Ecol. Lett. 9: 603-614.

Ricci C., Ponti L. \& Pires A. 2005: Migratory flight and prediapause feeding of Coccinella septempunctata (Coleoptera) adults in agricultural and mountain ecosystems of Central Italy. — Eur. J. Entomol. 102: 531-538.

Rоот R.B. 1973: Organization of a plant-arthropod association in simple and diverse habitats: the fauna of collards (Brassica oleracea). - Ecol. Monogr. 43: 95-124.

Roy H.E., Brown P.M.J., Comont R.F., Poland R.L. \& Sloggett J.J. 2013: Ladybirds. Pelagic Publishing, Exeter, 142 pp.

SALVETER R. 1998: The influence of sown herb strips and spontaneous weeds on the larval stages of aphidophagous hoverflies (Dipt., Syrphidae). - J. Appl. Entomol. 122: 103-114.

San Martin G. 2004: Clé de Détermination des Chrysopidae de Belgique. Jeune et Nature asbl, Wavre, 43 pp.

Schaller M. \& Nentwig W. 2000: Olfactory orientation of the seven-spot ladybird beetle, Coccinella septempuctata (Coleoptera: Coccinellidae): Attraction of adults to plants and conspecific females. - Eur. J. Entomol. 97: 155-159.

Service Public de Wallonie 2014: Cartes des Sols de Wallonie. URL: http://geoapps.wallonie.be/CigaleInter/\#CTX=CNSW\# $\mathrm{BBOX}=172556.38064514095,175228.67765640165,139464$ $.25249213536,140017.23276476256$ (last accessed 28 Nov. 2016).

Sutherland J.P., Sullivan M.S. \& Poppy G.M. 1999: The influence of floral character on the foraging behaviour of the hoverfly, Episyrphus balteatus. - Entomol. Exp. Appl. 93: 157-164.

TOOKER J.F., Hauser M. \& HANKS L.M. 2006: Floral host plants of Syrphidae and Tachinidae (Diptera) of central Illinois. - Ann. Entomol. Soc. Am. 99: 96-112.

Tscharntke T., Karp D.S., Chaplin-Kramer R., Batáry P., DeClerck F., Gratton C., Hunt L., Ives A.R., Jonsson M., LarsEN A. ET AL. 2016: When natural habitat fails to enhance biological pest control - Five hypotheses. - Biol. Conserv. 204: 449-458.

Tschumi M., Albrecht M., Entling M.H. \& Jacot K. 2014: Targeted flower strips effectively promote natural enemies of aphids. - IOBCwprs Bull. 100: 131-135.
Tschumi M., Albrecht M., Entling M.H. \& JAcot K. 2015: High effectiveness of tailored flower strips in reducing pests and crop plant damage. - Proc. R. Soc. (B) 282: 20151369, 8 pp.

Tschumi M., Albrecht M., Collatz J., Dubsky V., Entling M.H., NAJAR-Rodriguez A.J. \& JACOT K. 2016: Tailored flower strips promote natural enemy biodiversity and pest control in potato crops. - J. Appl. Ecol. 53: 1169-1176.

Turnbull L.A., Rees M. \& Crawley M.J. 1999: Seed mass and the competition/colonization trade-off: a sowing experiment. -J. Ecol. 87: 899-912.

Uyttenbroeck R., Hatt S., Paul A., Boeraeve F., Piqueray J., Francis F., Danthine S., Fréderich M., Dufrêne M., Bodson B. ET AL. 2016: Pros and cons of flowers strips for farmers: a review. - Biotechnol. Agron. Soc. Environ. 20: 225-235.

VAN RIJN P.C.J. \& WäCKERS F.L. 2010: The suitability of field margin flowers as food source for zoophagous hoverflies. IOBCwprs Bull. 56: 125-128.

VAN RIJN P.C.J. \& WÄCKERS F.L. 2016: Nectar accessibility determines fitness, flower choice and abundance of hoverflies that provide natural pest control. - J. Appl. Ecol. 53: 925-933.

VAn RiJn P.C.J., KoOIJMAn J. \& WäcKers F.L. 2013: The contribution of floral resources and honeydew to the performance of predatory hoverflies (Diptera: Syrphidae). - Biol. Contr. 67: 32-38.

VAN VeEn M.P. 2010: Hoverflies of Northwest Europe: Identification Keys to the Syrphidae. KNNV, Zeist, 248 pp.

Vandereycken A., Durieux D., Joie E., Sloggett J.J., Haubruge É. \& VerhegGen F.J. 2013: Is the multicolored Asian ladybeetle, Harmonia axyridis, the most abundant natural enemy to aphids in agroecosystems? - J. Insect Sci. 13(158): 14 pp.

Vattala H.D., Wratten S.D., Vattala C.B., Phillips F.L. \& WäCKERS F.L. 2006: The influence of flower morphology and nectar quality on the longevity of a parasitoid biological control agent. - Biol. Contr. 39: 179-185.

Venables W.N. \& Ripley B.D. 2002: Modern Applied Statistics with S. 4th ed. Springer, New York, $\mathrm{xi}+495 \mathrm{pp}$.

Ver Hoef J.M. \& Boveng P.L. 2007: Quasi-poisson vs. negative binomial regression: how should we model overdispersed count data? - Ecology 88: 2766-2772.

Villenave J., Deutsch B., Lodé T. \& Rat-Morris E. 2006: Pollen preference of the Chrysoperla species (Neuroptera: Chrysopidae) occurring in the crop environment in western France. Eur. J. Entomol. 103: 771-777.

Violle C., Navas M.-L., Vile D., Kazakou E., Fortunel C., HumMEL I. \& GARNIER E. 2007: Let the concept of trait be functional! - Oikos 116: 882-892.

WäCKERS F. 2004: Assessing the suitability of flowering herbs as parasitoid food sources: flower attractiveness and nectar accessibility. - Biol. Control 29: 307-314.

Wäckers F.L. \& VAN RiJn P.C.J. 2012: Pick and mix: selecting flowering plants to meet the requirements of target biological control insects. In Gurr G.M., Wratten S.D., Snyder W.E., \& Read D.M.Y. (eds): Biodiversity and Insect Pests: Key Issues for Sustainable Management. John Wiley \& Sons, Chichester, pp. 139-165.

Wratten S.D., Bowie M.H., Hickman J.M., Evans A.M., Sedcole J.R. \& TYLIANAKIS J.M. 2003: Field boundaries as barriers to movement of hover flies (Diptera: Syrphidae) in cultivated land. - Oecologia 134: 605-611.

Zhang W., Ricketts T.H., Kremen C., Carney K. \& Swinton S.M. 2007: Ecosystem services and dis-services to agriculture. -Ecol. Econ. 64: 253-260.

Received October 12, 2016; revised and accepted January 13, 2017 Published online January 27, 2017 
Table S1. Traits of each flower species considered to constitute the mixtures. Traits were retrieved from Lambinon et al. (2008) and the TRY database (Kattge et al., 2011).

\begin{tabular}{|c|c|c|c|c|c|c|c|}
\hline Flower species & Colour & $\begin{array}{c}\text { UV periphery } \\
(\%)\end{array}$ & $\begin{array}{c}\text { UV } \\
\text { pattern }\end{array}$ & $\begin{array}{l}\text { Blooming } \\
\text { start }\end{array}$ & $\begin{array}{l}\text { Blooming } \\
\text { duration } \\
\text { (months) }\end{array}$ & $\begin{array}{l}\text { Max. height } \\
\quad(\mathrm{cm})\end{array}$ & Flower type (Müller, 1881) \\
\hline Achillea millefolium & White & 3.5 & No & June & 6 & 45 & Associations with totally hidden nectar \\
\hline Anthriscus sylvestris & White & 3.5 & No & May & 2 & 120 & Open nectaries \\
\hline Crepis biennis & Yellow & 33.5 & Yes & June & 3 & 120 & Associations with totally hidden nectar \\
\hline Galium verum & Yellow & 3.5 & No & May & 5 & 80 & Open nectaries \\
\hline Geranium pyrenaicum & Violet & 76 & Yes & May & 5 & 60 & Totally hidden nectar \\
\hline Heracleum sphondylium & White & 3.5 & No & June & 3 & 150 & Open nectaries \\
\hline Hypericum perforatum & Yellow & 53 & Yes & July & 3 & 60 & Pollen flowers \\
\hline Hypochaeris radicata & Yellow & 33.5 & Yes & June & 4 & 60 & Associations with totally hidden nectar \\
\hline Knautia arvensis & Violet & 3.5 & No & June & 4 & 60 & Associations with totally hidden nectar \\
\hline Leontodon hispidus & Yellow & 53 & Yes & June & 5 & 40 & Associations with totally hidden nectar \\
\hline Leucanthemum vulgare & White & 3.5 & No & May & 4 & 60 & Associations with totally hidden nectar \\
\hline Lotus corniculatus & Yellow & 3.5 & No & May & 5 & 30 & Bee flowers \\
\hline Lythrum salicaria & Violet & 76 & Yes & June & 4 & 150 & Totally hidden nectar \\
\hline Malva moschata & Violet & 53 & Yes & July & 3 & 80 & Totally hidden nectar \\
\hline Medicago Iupulina & Yellow & 3.5 & No & April & 7 & 50 & Hymenoptera flowers \\
\hline Origanum vulgare & Violet & 11.5 & No & July & 3 & 80 & Totally hidden nectar \\
\hline Prunella vulgaris & Violet & 76 & Yes & July & 3 & 50 & Hymenoptera flowers \\
\hline Ranunculus acris & Yellow & 21.5 & Yes & May & 5 & 90 & Partly hidden nectar \\
\hline Silene latifolia & White & 21.5 & Yes & May & 6 & 90 & Moth flowers \\
\hline Trifolium pratense & Violet & 3.5 & No & May & 6 & 50 & Bee flowers \\
\hline
\end{tabular}

